\title{
The Synthesis of Thiosemicarbazone-Based Aza-Ylides as Inhibitors of Rat Erythrocyte Glucose 6-Phosphate Dehydrogenase Enzyme
}

\author{
Yusuf TEMEL $^{1 *}$, Sinan BAYIDIR ${ }^{2}$
}

\begin{abstract}
Glucose 6-phosphate dehydrogenase (G6PD) enzyme plays an important role in various biochemical processes such as synthesis of cholesterol, fatty acids, sphingosine, steroid hormones, NADPH, some amino acids and ribose 5-phosphate. In this study, thiosemicarbazone-based aza-ylide (TSCAs) derivatives 3a-3e, which form the main framework of many drugs such as thioacetazone, ambazone, and perchlozone, were synthesized with a green approach and in vitro inhibitor or activator effects on G6PD enzyme activity was investigated. As a result of studies, TSCAs derivatives 3a-3d inhibited the G6PD enzyme activity with $\mathrm{IC}_{50}$ in the range of $40.77 \mu \mathrm{M}$ to $58.0 \mu \mathrm{M}$ for G6PD.
\end{abstract}

Keywords: Thiosemicarbazone, aza-ylide, rat erythrocyte, enzyme, G6PD

\section{Sıçan Eritrosit Glukoz 6-Fosfat Dehidrogenaz Enzim İnhibitörleri Olarak Tiyosemikarbazon Temelli Aza-Ylidlerin Sentezi}

ÖZET: Glukoz 6-fosfat dehidrogenaz (G6PD) enzimi NADPH, bazı amino asitler, sfingozin, steroid hormonlar1, kolesterol, yă asitleri ve riboz 5-fosfat sentezi gibi pek çok biyokimyasal prosesin gerçekleşmesinde çok önemli bir role sahiptir. Bu çalışmada, tiyoasetazon, ambazon ve perklozon gibi birçok ilacın ana iskeletini oluşturan tiyosemikarbazon temelli aza-ylid (TSCAs) türevi 3a-3e moleküllerinin sentezi çevreci bir yaklaşımla gerçekleştirilerek, G6PD enzim aktivitesi üzerine in vitro şartlarda inhibisyon ve aktivasyon etkisi araştırılmıştır. Çalışmalar neticesinde, sentezlenen TSCAs türevleri 3a-3d moleküllerinin G6PD enzim aktivitesini $40.77 \mu \mathrm{M}$ ile $58.0 \mu \mathrm{M}$ aralığındaki $\mathrm{IC}_{50}$ değerlerinde inhibe ettiği belirlenmiştir.

Anahtar Kelimeler: Tiyosemikarbazon, aza-ylid, sıçan eritrosit, enzim, G6PD

\footnotetext{
${ }^{1}$ Yusuf TEMEL (Orcid ID: 0000-0001-8148-3718), Department of Health Services, Vocational Schools, Bingol University, Bingol, Turkey

2 Sinan BAYINDIR (Orcid ID: 0000-0002-7845-4497), Department of Chemistry, Faculty of Sciences and Arts, Bingol University, Bingol, Turkey

* Sorumlu Yazar/Corresponding Author:Yusuf TEMEL, e-mail: ytemel@bingol.edu.tr 


\section{INTRODUCTION}

To date, a plurality of synthesized organic molecules including functional groups such as alcohol, acid, esters and aldehyde groups have been reported as important enzyme inhibitors (Zhao et al., 2013; Ebrahimi et al., 2015). Unfortunately, these compounds are not ideal enough due to their dissatisfied activity and undesirable toxic side effects (Lin et al., 2014). In the last years, thiosemicarbazone-appended aromatic compounds have been receiving significant attention in the area of medicine and biochemistry because of their promising biological effects and exceptional pharmacological properties such as antimicrobial<smiles>CC(=O)Nc1ccc(/C=N/NC(N)=S)cc1</smiles>

Thioacetazone
(Costello et al., 2008), anti-HIV-1 (Pelosi et al., 2010), anticancer (Jimbow et al., 2000; Yusuf et al., 2014). However, the rich chemistry of thiosemicarbazone (1) and importance of the heterocyclic (Hassan et al., 2011; Gazieva et al., 2012) and metal complexes (Şahin et al., 2010; Pelosi et al., 2010; Netalkar at al., 2015) being steadily derived from this, encourage the further development of the green synthetic methods in this field (Bayindir et al., 2019). A number of popular drugs such as thioacetazone, ambazone (Kleemann et al., 2001) and perchlozone (Smolentsev et al., 2009) are included thiosemicarbazone core (Malkina et al. 2017) (Figure 1).<smiles>N=C(N)NN=C1C=CC(=NNC(N)=S)C=C1</smiles>

Ambazone

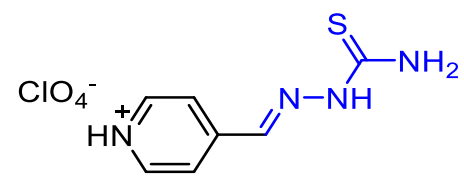

Perchlozone

Figure 1. Medicines derived based on thiosemicarbazide

The pentose phosphate pathway (hexose monophosphate shunt, PPP) occurs in the cytosol of many organisms. This process is an alternative pathway for glucose oxidation. The PPP has two vital functions in terms of cell; one of is production of NADPH, which is used as a reducing power in many biosynthetic reactions such as synthesis of cholesterol, fatty acids, steroid hormones, sphingosine, and some amino acids and it is also important for protection against oxidative damage of cell (Bruinenberg et al., 1983; Thomas et al., 1991); and the other function is synthesis of ribose 5-phosphate.
Ribose, a five-carbon compound, and its metabolic product, deoxyribose form the sugar skeleton of RNA and DNA. These products are play key roles in dividing cells. In addition, ribose is involved in the production of many metabolic intermediates such as AMP, ADP, ATP, cAMP, coenzyme A, FAD, $\mathrm{NADP}^{+}$and NADPH (Cuperlovic, 2013). Glucose 6-phosphate dehydrogenase (EC 1.1.1.49, G6PD, NADP ${ }^{+}$ oxidoreductase) enzyme is the first and the key regulatory biocatalyst in the pentose phosphate pathway involved in carbohydrate metabolism. The G6PD enzyme catalyzes conversion reaction 
(irreversible) of glucose 6-phosphate to 6phosphoglucono- $\delta$-lactone in the presence of $\mathrm{NADP}^{+}$(Çiftci et al., 2001, Beydemir et al., 2003, Çiftci et al., 2003). The G6PD enzyme is also associated with some diseases such as some metabolic disorders, some cancer type, and cardiovascular diseases (Zhang et al., 2014, Hacker et al., 2012).

The thiosemicarbazone derivatives synthesizing and investigating their potential inhibitory actions are very important. However, there is no study investigating the effect of thioacetazone derivatives on metabolic enzymes including G6PD. For this purpose in the present study, we synthesized of thiosemicarbazonebased aza-ylide (TSCAs) derivatives (3a-3e), which have differed nature, by a green synthetic approach and investigated their inhibition effects on rat erythrocyte G6PD enzyme activity.

\section{MATERIALS AND METHODS}

\section{General Information}

All solvents and chemicals were commercially available from Fluka or SigmaAldrich. All ${ }^{1} \mathrm{H}$ NMR and ${ }^{13} \mathrm{C}$ NMR spectra were recorded on 400 (100)-MHz Bruker spectrometer. The mixture reaction was monitored by thin layer chromatography (TLC) plates (Merck, 60 F254). UV-vis spectra were monitored on Shimadzu UV-1800 UV/Visible.

\section{Synthesis of Organic Compounds and Enzyme Activity Studies}

General procedure for synthesis of thiosemicarbazones aza-ylides (3a-3e): To a solution of aldehydes (2a-2e, 1.0 equiv.) in ethanol $(10 \mathrm{~mL})$ was added slowly to the solution of thiosemicarbazide (1, 1.0 equiv.). The reaction mixture was refluxed without any catalyst for between $5 \mathrm{~h}$ and $12 \mathrm{~h}$, and was monitored by TLC. After, the mixture product was recrystallized from EtOH. After recrystallization, thiosemicarbazone-based aza-ylide derivatives (3a-3e) was obtained as following.
(E)-2-Benzylidenehydrazine-1carbothioamide (3a): White solid, m. p. 162$163^{\circ} \mathrm{C}$, yield $75 \% .{ }^{1} \mathrm{H}-\mathrm{NMR}$ (400 $\mathrm{MHz}, \mathrm{CDCl}_{3}$ ): $\delta 11.44(\mathrm{~s}, 1 \mathrm{H}, \mathrm{NH}), 8.22$ (bs, $\left.1 \mathrm{H}, \mathrm{NH}_{2}\right), 8.05$ (s, $1 \mathrm{H},=\mathrm{CH}), 8.00\left(\mathrm{bs}, 1 \mathrm{H}, \mathrm{NH}_{2}\right), 7.80-7.78(\mathrm{~m}, 2 \mathrm{H}$, $=\mathrm{CH}), \quad 7.40-7.38(\mathrm{~m}, 3 \mathrm{H},=\mathrm{CH}) ;{ }^{13} \mathrm{C} \mathrm{NMR}$ (DMSO-d6) $\delta$ 180.0, 144.2, 136.2, 131.8, 130.7, 129.3. All spectroscopic data for $3 \mathrm{a}$ is compatible with the literature (Lee et al. 2010; Thanigaimalai et al. 2010).

(E)-2-(2-Hydroxybenzylidene)hydrazine-1carbothioamide (3b): Pale yellow solid, m. p. 228-230 ${ }^{\circ} \mathrm{C}$, yield $87 \%$. ${ }^{1} \mathrm{H}-\mathrm{NMR}(400 \mathrm{MHz}$, DMSO-d6): $\delta 11.35$ (s, 1H, NH), 9.88 (bs, $1 \mathrm{H}$, $\mathrm{OH}), 8.37$ (s, $1 \mathrm{H}, \mathrm{N}=\mathrm{CH}), 8.12\left(\mathrm{bs}, 1 \mathrm{H}, \mathrm{NH}_{2}\right)$, 7.93 (bs, $1 \mathrm{H}, \mathrm{NH}_{2}$ ), 7.91 (bs, $\left.1 \mathrm{H},=\mathrm{CH}\right), 7.23-7.19$ $(\mathrm{m}, 1 \mathrm{H},=\mathrm{CH}), 6.87-6.79(\mathrm{~m}, 2 \mathrm{H},=\mathrm{CH}) ;{ }^{13} \mathrm{C}-$ NMR (100 MHz, $\left.\mathrm{CDCl}_{3}\right): \delta 177.6,156.4,139.6$, 131.1, 126.7, 120.3, 119.2, 116.0. All spectroscopic data for $3 b$ is compatible with the literature (Kuznetsova et al. 2014).

(E)-2-(Pyridin-4-ylmethylene)hydrazine-1carbothioamide (3c): White solid, yield $94 \% .{ }^{1} \mathrm{H}$ NMR (400 MHz, DMSO-d6) $\delta 11.56$ (s, 1H, NH), 8.56 (s, 2H, NH $\left.\mathrm{N}_{2}\right), 8.60$ (s, 1H, CH), 8.66 (s, 1H, $=\mathrm{CH}), 7.98(\mathrm{~s}, 1 \mathrm{H},=\mathrm{CH}), 7.98(\mathrm{~s}, 1 \mathrm{H},=\mathrm{CH}), 8.66$ $(\mathrm{s}, 1 \mathrm{H},=\mathrm{CH}) .{ }^{13} \mathrm{C}$ NMR $(100 \mathrm{MHz}, \mathrm{DMSO}-d 6) \delta$ 178.5, 149.5, 146.9, 144.4, 120.4. All spectroscopic data for $3 \mathrm{c}$ is compatible with the literature (Lee et al., 2010).

(E)-2-(Pyren-1-ylmethylene)hydrazine-1carbothioamide (3d): Red solid, m. p. 238-240 ${ }^{\circ} \mathrm{C}$, yield 91\%. ${ }^{1} \mathrm{H}-\mathrm{NMR}$ (400 MHz, DMSO-d6): $\delta 11.58(\mathrm{~s}, 1 \mathrm{H}, \mathrm{NH}), 9.27(\mathrm{~s}, 1 \mathrm{H},=\mathrm{CH}), 8.90(\mathrm{~d}$, $J=8.2 \mathrm{~Hz}, 1 \mathrm{H},=\mathrm{CH}), 8.48(\mathrm{~d}, J=8.2 \mathrm{~Hz}, 1 \mathrm{H}$, $=\mathrm{CH}), 8.36-8.21\left(\mathrm{~m}, 8 \mathrm{H},=\mathrm{CH}, \mathrm{NH}_{2}\right), 8.12(\mathrm{t}, J=$ $8.2 \mathrm{~Hz}, 1 \mathrm{H},=\mathrm{CH}) ;{ }^{13} \mathrm{CNMR}(100 \mathrm{MHz}$, DMSO$d 6): \delta 177.8(\mathrm{C}=\mathrm{S}), 140.2,131.8,130.8,130.1$, $128.7,128.6,128.2,127.4,126.9,126.5,126.0$, $125.7,125.1,124.2,124.0,123.8,121.6$. All spectroscopic data for $3 \mathrm{~d}$ is compatible with the literature (Wang et al., 2010; Ghosh et al., 2012; Bayindir et al., 2019). 
(E)-2-(2-Oxoindolin-3-ylidene)hydrazine-1carbothioamide (3e): Yellow solid, m.p. $>300^{\circ} \mathrm{C}$, yield 94\%. ${ }^{1} \mathrm{H}-\mathrm{NMR}(400 \mathrm{MHz}, \mathrm{DMSO}-d 6): \delta$ 12.47 (s, 1H, NH), $11.21(\mathrm{~s}, 1 \mathrm{H}, \mathrm{C}=\mathrm{NH}), 9.05$ (bs, $\left.1 \mathrm{H}, \mathrm{NH}_{2}\right), 8.70\left(\mathrm{bs}, 1 \mathrm{H}, \mathrm{NH}_{2}\right), 7.66(\mathrm{~d}, J=8.0 \mathrm{~Hz}$, $1 \mathrm{H},=\mathrm{CH}), 7.36(\mathrm{t}, J=8.0 \mathrm{~Hz}, 1 \mathrm{H},=\mathrm{CH}), 7.09(\mathrm{t}$, $J=8.0 \mathrm{~Hz}, 1 \mathrm{H},=\mathrm{CH}), 6.93(\mathrm{~d}, J=8.0 \mathrm{~Hz}, 1 \mathrm{H}$, $=\mathrm{CH}) ;{ }^{13} \mathrm{C}-\mathrm{NMR}(100 \mathrm{MHz}, \mathrm{DMSO}-d 6): \delta 180.1$, 163.3, 143.1, 132.4, 131.6, 122.8, 121.1, 120.7, 111.5. All spectroscopic data for $3 \mathrm{e}$ is compatible with the literature (Lin et al., 2010; Sarıüney et al., 2014).

Preparation of hemolysate: The rat blood samples placed in anticoagulant-containing tubes. In order to seperate the erythrocytes blood samples were centrifuged for $15 \mathrm{~min}$ at $2500 \mathrm{x} \mathrm{g}$. After removal of plasma and leukocyte layer, the precipitate were washed three times with serum isotonic $(0.16 \mathrm{M} \mathrm{KCl})$ and hemolyzed with 5 times of cold-water. Then, in order to remove the ghost and intact cells 30 minutes centrifugation process were conducted at $10.000 \times \mathrm{g}$ (Temel and Kocyigit, 2017; Aslan et al. 2018).

Purification of G6PD enzyme: After the hemolysate preparation process, prepared hemolysate was loaded the 2',5'-ADP Sepharose 4B Affinity column, and following column equilibrated with $50 \mathrm{mM} \mathrm{KH} \mathrm{PO}_{4}, 1 \mathrm{mM}$ EDTA and $1 \mathrm{mM}$ DTT at $\mathrm{pH} 7.3$ buffer solution. The G6PD enzyme was eluted with $80 \mathrm{mM} \mathrm{KH}_{2} \mathrm{PO}_{4}$, $10 \mathrm{mM}$ EDTA, $80 \mathrm{mM} \mathrm{KCI}$ and $5 \mathrm{mM} \mathrm{NADP}^{+}$at $\mathrm{pH} 7.3$ solution. All process were carried out at $4^{\circ} \mathrm{C}$ (Kirici et al. 2016: Temel and Kocyigit, 2017).

Measurement of G6PD enzyme activity: G6PD enzyme activity was detrmined according to Beutler's method. This method depend on the measurement of the absorbance of NADPH at 340 $\mathrm{nm}$ by spectrophotometrically (Beutler, 1971).

In vitro enzyme inhibition studies: In this study, we synthesized thiosemicarbazone derivatives to determine inhibition profiles on G6PD enzyme activity purified from rat erythrocytes. To determine $\mathrm{IC}_{50}$ values (causing a $50 \%$ decrease in enzyme activity) were added $0.60 \mathrm{mM}$ constant substrate (G6P) and different concentrations thiosemicarbazone derivatives to the reaction medium in $1 \mathrm{~mL}$ of total reaction volume. The inhibitor concentrations ( $\mathrm{IC}_{50}$ values) were calculated via activity \%-vs compound concentration graphs. The $\mathrm{K}_{\mathrm{i}}$ values and the types of enzymatic inhibition were determined via Lineweaver-Burk graphs (Lineweaver and Burk 1934). The study was carried out approval form taken from Local Ethic Committee of Animal Experiments of Bingol University (85680299/020).

\section{RESULTS AND DISCUSSION}

\section{Synthesis of Organic Compounds}

As mentioned above, in this work we interested in the synthesis and their enzyme activity of some thiosemicarbazone-based azaylide derivatives starting from commercially available thiosemicarbazone and aldehydes. For this purpose, thiosemicarbazone-based aza-ylide derivatives (3a-3e) were synthesized via reaction of aldehydes $2 \mathrm{a}-2 \mathrm{e}$, which have different natures, with hydrazinecarbothioamide (1) without any catalyst. Detailed procedures and characterization can be found in the experimental section and Figure 2 for $3 b$ and $3 e$. 


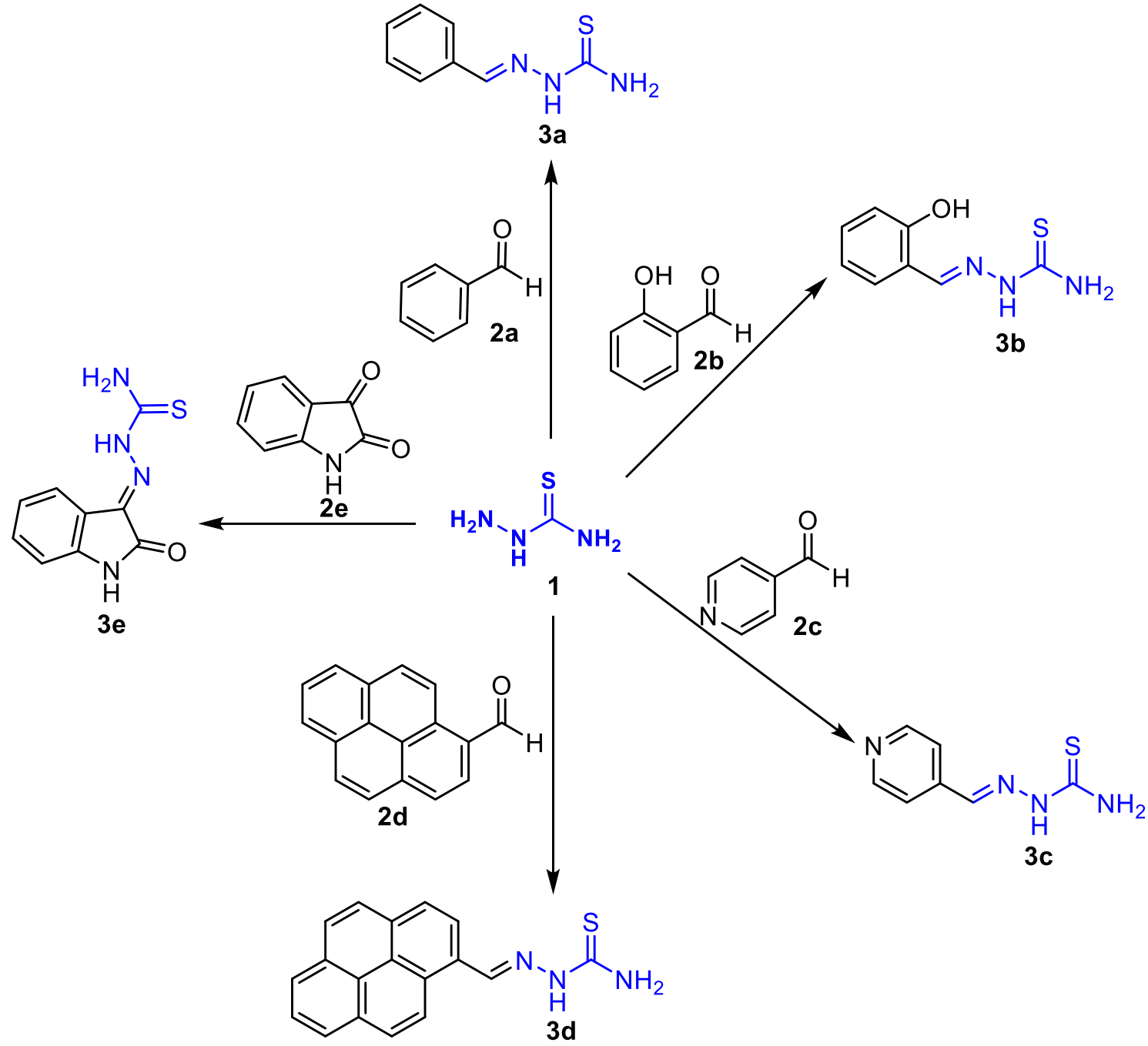

Scheme 1. Synthesis of thiosemicarbazone-based aza-ylide derivatives (3a-3e)

In this study, the synthesis of thiosemicarbazone-based aza-ylide derivatives (3a-3e) was carried out with a green approach and the rat erythrocyte G6PD enzyme inhibition properties of $3 \mathrm{a}-3 \mathrm{e}$ were examined. The ${ }^{1} \mathrm{H}$ NMR spectra of $3 b$ and $3 e$, which are have different nature, are shown in Figure 2. When the ${ }^{1} \mathrm{H}$ NMR spectrum of $3 \mathrm{~d}$ and $3 \mathrm{e}$ are examined, it is seen that the $\mathrm{NH}$ (of $\mathrm{N}-\mathrm{NH}-\mathrm{C}=\mathrm{S}$ group) proton peaks are resonance at $11.35(\mathrm{~s}, \mathrm{~N}=\mathrm{NH}, 1 \mathrm{H}) \mathrm{ppm}$ and 11.21 (s, N-NH, 1H) ppm, respectively. At the same time, it is seen that protons of $\mathrm{S}=\mathrm{C}-\mathrm{NH}_{2}$ groups in the structure of the target molecules gave resonances signals at $8.12\left(\mathrm{bs}, \mathrm{NH}_{2}, 1 \mathrm{H}\right), 7.93$ (bs, $\mathrm{NH}_{2}, 1 \mathrm{H}$ ) ppm and 9.05 (bs, $\left.\mathrm{NH}_{2}, 1 \mathrm{H}\right), 8.70$ (bs, $\mathrm{NH}_{2}, 1 \mathrm{H}$ ) ppm, respectively (Figure $2 \mathrm{~A}$ and $2 \mathrm{~B}$ ).
All spectroscopic data for thiosemicarbazonebased aza-ylide derivatives 3a-3e synthesized with a green approach are compatible with the literature.

\section{In Vitro Enzyme Kinetic Studies}

The pentose phosphate pathway controlled by the G6PD enzyme has vital functions for the cell, such as synthesizing the intracellular reducing power, ensuring the redox balance, the synthesis of lipids, certain amino acids, certain hormones and nucleotides. Also G6PD plays an important role in proliferation, survival and metastasis of cancer cells. Discovery of novel and potent G6PD inhibitory agents might provide new approaches for cancer therapy (Zhang et al., 2014). 
(A)<smiles>[2H]c1c(P)c(C)c(Cl)c2c1/C(=N/NC(N)=S)C(=O)N2</smiles>

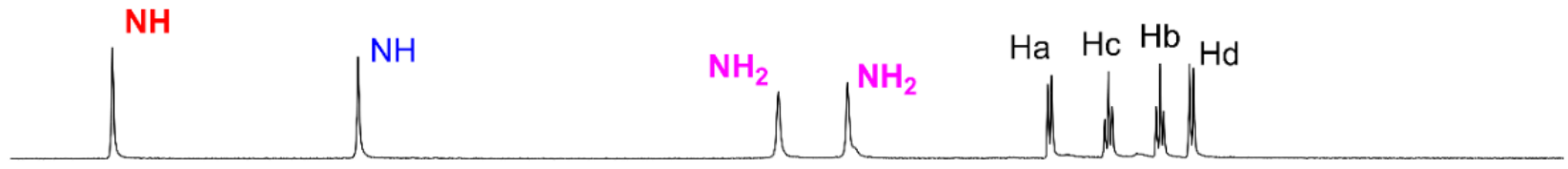

(B)<smiles>[2H]c1c(C)c(O)c(/C=N/NC(N)=S)c(O)c1P</smiles>

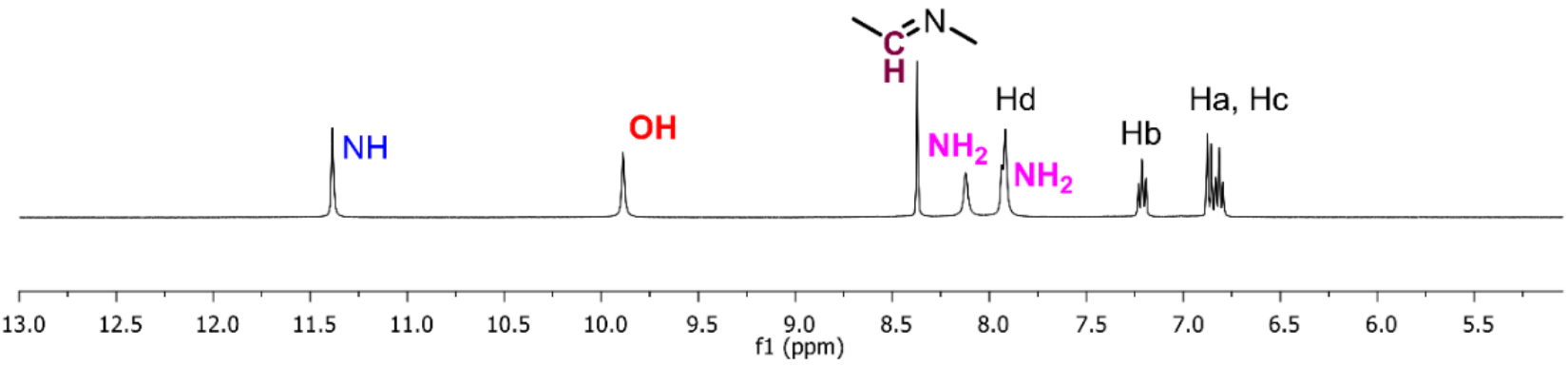

Figure 2. ${ }^{1} \mathrm{H}$ NMR spectrums of $3 \mathrm{e}(\mathrm{A})$ and $3 \mathrm{~b}(\mathrm{~B})$

Along with the purification studies on the G6PD enzyme, although the effects of the inorganic compounds are quite a number of studies (Temel et al., 2017, Bayramoğlu et al., 2018, Temel and Tays1, 2018), there are a limited number of studies on the effects of organic based compounds (drug analog or candidate) on the enzyme activity (Bayindir et al., 2018a, Bayindir et al., 2018b, Temel et al., 2018).Although the effects of thiosemicarbazone derivatives, which were synthesized in the scope of this study and which constitute the main skeleton of important drugs, were studied on various enzymes, no studies have been conducted on G6PD enzyme. In this context, it is important to investigate the effects of these skeletons on the activity of G6PD enzyme.

In this study G6PD enzyme was purified in a single chromatographic step with $2^{\prime}, 5^{\prime}$-ADP
Sepharose 4B Affinity column chromatography from rat erythrocytes. Following purification of enzyme, we investigated the effect of G6PD with a series of thiosemicarbazone-based aza-ylide derivatives (3a-3e). While the thiosemicarbazone-based aza-ylide derivatives (3a-3d) had effective inhibition effects against G6PD enzyme, 3e had not any effect against G6PD. The inhibition effect observed with these derivatives on G6PD enzyme activity are shown in Table 1. According to Table 1 and Fig. 3, the $\mathrm{IC}_{50}$ values were found in the range of 40.77$58.01 \mu \mathrm{M}$ towards G6PD enzyme (Entry 1-4).

Bayindir et al. found that new synthesized $N$-benzoylindole compounds inhibited G6PD enzyme with $\mathrm{IC}_{50}$ values in the range of $3.39 \mu \mathrm{M}$ to $1505 \mu \mathrm{M}$ (Bayindir et al., 2018b). In a different study, the effects of synthesized new oxindole compounds on G6PD and 6PGD enzyme 
activities were investigated. As a result of this study, it was determined that the synthesized compounds inhibited the G6PD enzyme with $\mathrm{IC}_{50}$ values in the range of $99 \mu \mathrm{M}-304 \mu \mathrm{M}$. Compared with other studies, $\mathrm{IC}_{50}$ and $\mathrm{K}_{\mathrm{i}}$ values, which are
40.77-58.01 $\mu \mathrm{M}$ for $\mathrm{IC}_{50}$ and 53.79-62.26 $\mu \mathrm{M}$ for $\mathrm{K}_{\mathrm{i}}$, were found near together. These results imply that the binding morphology of these molecules is similar (Table 1, Entry 1-4).
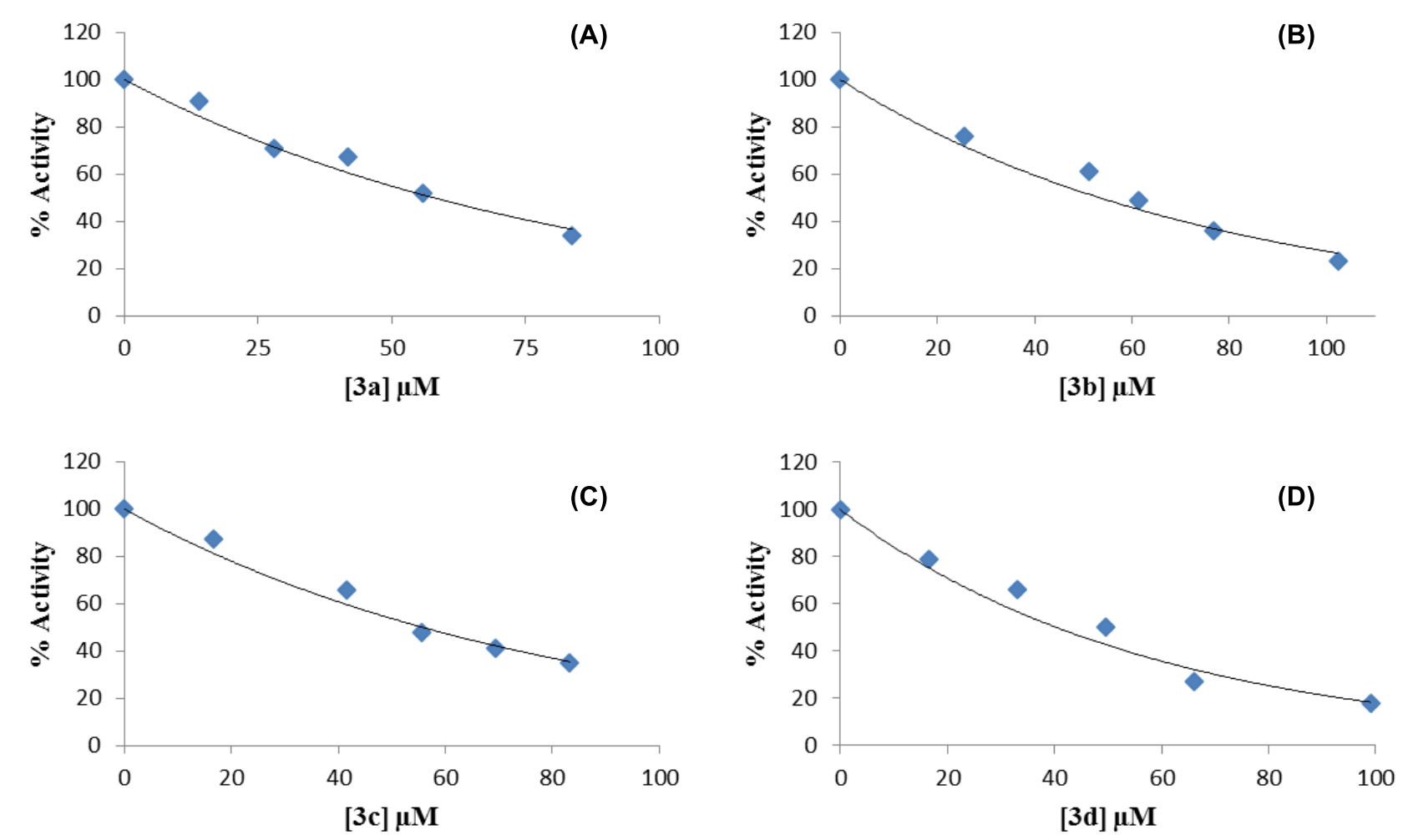

Figure 3. IC50 graphs of $\boldsymbol{T S C A}$ derivatives 3a (A), 3b (B), 3c (C) and 3d (D) on rat erythrocyte G6PD enzyme

Table 1. The determination of $\mathrm{IC}_{50}, \mathrm{~K}_{\mathrm{i}}$ values and inhibition types of the TSCAs

\begin{tabular}{rlccc}
\hline Entry & Compounds & Inhibition type & IC $\mathbf{5 0}_{(\boldsymbol{\mu M})}$ & $\mathbf{K}_{\mathbf{i}}(\boldsymbol{\mu} \mathbf{M})$ \\
\hline $\mathbf{1}$ & $\mathbf{3 a}$ & Non- Competitive & 58.01 & 62.26 \\
$\mathbf{2}$ & $\mathbf{3 b}$ & Non- Competitive & 53.30 & 53.79 \\
$\mathbf{3}$ & $\mathbf{3 c}$ & Non- Competitive & 57.71 & 53.92 \\
$\mathbf{4}$ & $\mathbf{3 d}$ & Non- Competitive & 40.77 & 57.63 \\
$\mathbf{5}$ & $\mathbf{3 e}$ & No effect & - & - \\
\hline
\end{tabular}

Studies with G6PD suggested that the least effective thiosemicarbazone-based aza-ylide derivative was $3 \mathrm{e}$, which did not affect the enzymatic activity up to a concentration in the range of 2.25-11.25 $\mu \mathrm{M}$ (Table 1, Entry 5). For G6PD enzyme, the $K_{i}$ values were found in the range of 53.79-62.26 $\mu \mathrm{M}$. (Table 1, Entry 1-4, and Fig. 4). This inhibition results clearly indicated that thiosemicarbazone-based aza-ylide derivatives (3a-3d), which are synthesized compounds, had efficient non-competitive enzymes inhibition effect. As a result of studies, the most potent inhibitory effect on G6PD enzyme activity was obtained by thiosemicarbazone-based aza-ylide derivatives $3 \mathrm{~b}$ with $\mathrm{K}_{\mathrm{i}}$ values of $53.79 \mu \mathrm{M}$. 


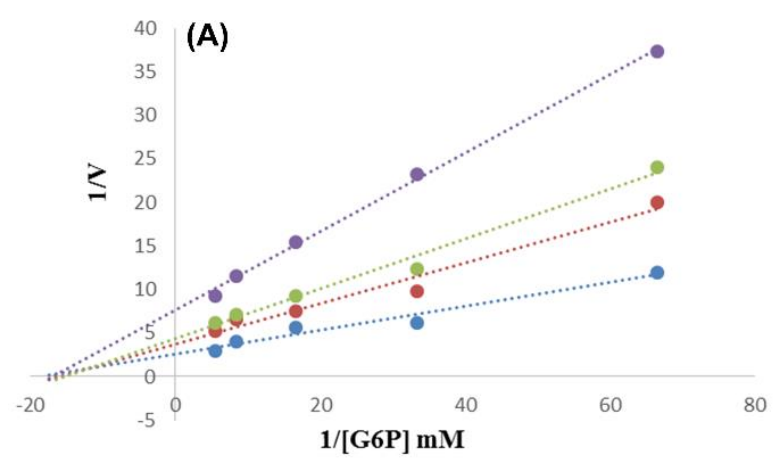

(C)

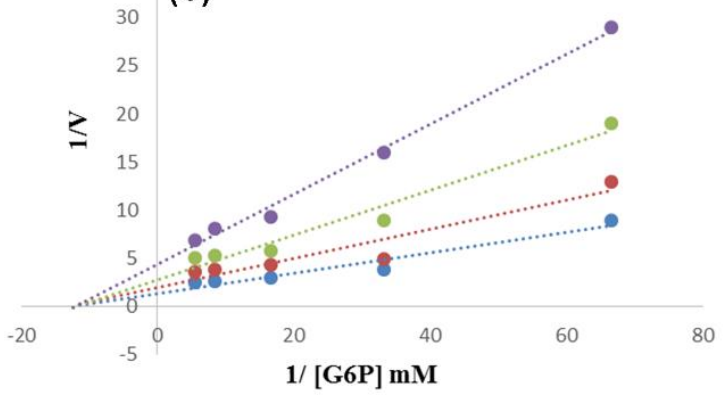

Figure 4. $\mathrm{K}_{\mathrm{i}}$ graphs of $\boldsymbol{T S C A}$ derivatives $3 \mathbf{a}(\mathrm{A}), \mathbf{3 b}$

\section{CONCLUSION}

In this study, the inhibitory effects of thiosemicarbazone-based aza-ylide derivatives (TSCAs) 3a-3e on important enzyme of pentose phosphate pathway, G6PD were investigated in vitro. Initially, thiosemicarbazone-based azaylide derivatives $3 \mathrm{a}-3 \mathrm{e}$, which are the skeleton of natural and important medicinal chemicals such as thioacetazone, ambazone, and perchlozone, were synthesized via a green approach without catalyst. Following synthesis, TSCAs derivatives 3a-3e were investigated for their G6PD inhibition properties. The results suggested that TSCAs derivatives $3 \mathrm{a}-3 \mathrm{~d}$ except $3 \mathrm{e}$ were moderate inhibitors of the rat erythrocyte G6PD enzyme. As a result of studies, TSCAs inhibited the G6PD enzyme activity with $\mathrm{IC}_{50}$ in the range of 40.77 $\mu \mathrm{M}$ and $58.0 \mu \mathrm{M}$ for G6PD.

\section{ACKNOWLEDGEMENT}

Authors are indebted to Department of Chemistry and Vocational Schools at Bingol University for their finical support.
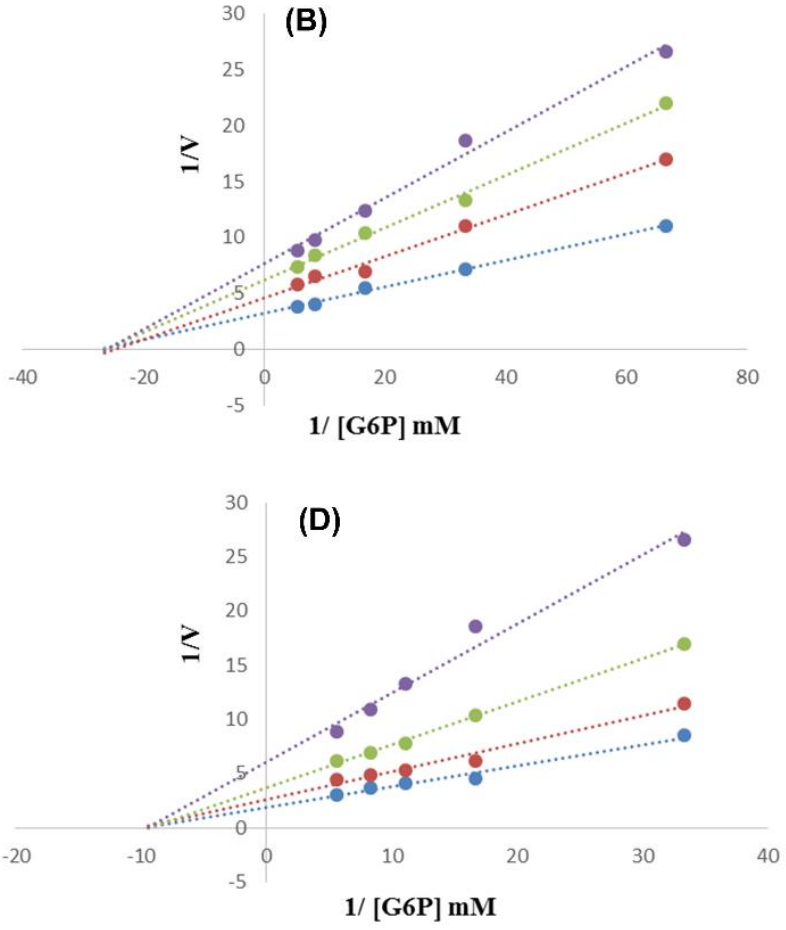

(B), 3c (C) and 3d (D) on rat erythrocyte G6PD enzyme

\section{REFERENCES}

Aslan, H. E., Demir, Y., Özaslan, M. S., Türkan, F., Beydemir, Ş., Küfrevioğlu, Ö. I., (2018). The behavior of some chalcones on acetylcholinesterase and carbonic anhydrase activity. Drug Chem. Toxicol. 4: 1-7.

Bayindir S., Toprak M., 2019, A novel pyrene-based selective colorimetric and ratiometric turn-on sensing for copper, Spectrochimica Acta Part A: Molecular and Biomolecular Spectroscopy 213: 6-11.

Bayindir, S., Ayna, A., Temel, Y., Ciftci, M. 2018a. The synthesis of new oxindoles as analogs of natural product 3, 3'-bis (indolyl) oxindole and in vitro evaluation of the enzyme activity of G6PD and 6PGD. Turkish Journal of Chemistry, 42(2): 332345.

Bayindir, S., Temel, Y., Ayna, A., Ciftci, M. 2018b. The synthesis of N-benzoylindoles as inhibitors of rat erythrocyte glucose-6-phosphate dehydrogenase and 6-phosphogluconate dehydrogenase. Journal of biochemical and molecular toxicology, 32(9): e22193. 
Bayramoğlu Akkoyun, M., Bengü, A. Ş., Temel, Y., Akkoyun, H. T., Ekin, S., Ciftci, M. 2018. The effect of astaxanthin and cadmium on rat erythrocyte G6PD, 6PGD, GR, and TrxR enzymes activities in vivo and on rat erythrocyte 6PGD enzyme activity in vitro. Journal of biochemical and molecular toxicology, 32(8): e22170.

Beutler, E., 1971. "Red cell metabolism manual of biochemical methods", London Academic Press: 19-68,

Beydemir, S., GüLCIN, I., Küfrevioğlu, O. I., Ciftçi, M. 2003. Glucose 6-phosphate dehydrogenase: in vitro and in vivo effects of dantrolene sodium. Polish journal of pharmacology, 55(5): 787-792.

Bruinenberg, PM., Van Dijken, JP., Scheffers, WA., 1983. "A theoretical analysis of NADPH production and consumption in yeasts", J. Gen. Microbiol. 129: 953-964,

Çiftçi, M., Beydemir, Ş., Yılmaz, H., Altıkat, S. (2003). Purification of glucose 6-phosphate dehydrogenase from Buffalo (Bubalus bubalis) erythrocytes and investigation of some kinetic properties. Protein expression and purification, 29(2): 304-310.

Çiftci, M., Özmen, İ., Büyükokuroğlu, M. E., Pençe, S., Küfrevioğlu, Ö. İ. (2001). Effects of metamizol and magnesium sulfate on enzyme activity of glucose 6-phosphate dehydrogenase from human erythrocyte in vitro and rat erythrocyte in vivo. Clinical biochemistry, 34(4): 297-302.

Costello C., Karpanen T., Lambert P.A., Mistry P., Parker K.J., Rathbone D.L., Ren, Wheeldon L.J.M., Worthington $\quad$ T., 2008. Thiosemicarbazones active against Clostridium difficile, Bioorg. Med. Chem. Lett 18: 1708-1711.

Cuperlovic-Culf, M., 2013. "NMR metabolomics in cancer research", Burlington, Elsevier Science,

Ebrahimi H.P., Hadi J.S., Alsalim T.A., Ghali T.S., Bolandnazar Z., 2015. A novel series of thiosemicarbazone drugs: from synthesis to structure. Spectrochim. Acta -Part A Mol. Biomol. Spectrosc. 137: 1067-1077.

Gazieva, G.A.; Kravchenko, A.N., 2012. Thiosemicarbazides in the synthesis of five- and six-membered heterocyclic compounds. Russ. Chem. Rev. 81: 494-523.
Ghosh P., Mandal S., Das T., Maity A., Gupta P., Purkayastha P., 2012. "Extra stabilization" of a pyrene based molecular couple by C-cyclodextrin in the excited electronic state. Phys. Chem. Chem. Phys. 14: 11500-11507.

Hassan, A.A.; Shawky, A.M., 2011. Thiosemicarbazides in heterocyclizationJ. Heterocycl. Chem. 48: 495516.

Hecker, P. A., Leopold, J. A., Gupte, S. A., Recchia, F. A., Stanley, W. C. 2012. Impact of glucose-6phosphate dehydrogenase deficiency on the pathophysiology of cardiovascular disease. American Journal of Physiology-Heart and Circulatory Physiology, 304(4): 491-500.

Jimbow K., Hua C., Gomez P.F., Hirosaki K., Shinoda K., Salopek T.G., Matsusaka H., Jin H.Y., Yamashita T., 2000. Intracellular vesicular trafficking of tyrosinase gene family protein in $\mathrm{Eu}-$ and pheomelanosome biogenesis, Pigm. Cell Res. 13: 110-117.

Kirici, M., Demir, Y., Beydemir, S., Atamanalp, M., 2016. The Effect Of $\mathrm{Al}^{+3}$ And $\mathrm{Hg}^{+2}$ On Glucose 6-Phosphate Dehydrogenase From Capoeta Umbla Kıdney. Appl Ecol Env Res. 14(2): 253264.

Kleemann A., Engel J., Kutscher B., Reichert D., 2001. Pharmaceutical Substances: Syntheses, Patents, Applications; Thieme: Stuttgart, pp. 77-78.

Kuznetsova M.A., Bespalov A.Y., 2014. One-Pot, Three-Component Synthesis of [1,3] thiazolo[4,3-B][1,3,4]thiadiazoles: Correct Structure Of The Products, Chemistry of Heterocyclic Compounds, 49: 1458-1463.

Lee K.C., Thanigaimalai P., Sharma V.K., Kim M.S., Roh E., Hwang B.Y., Kim Y., Jung S.H., 2010. Structural characteristics of thiosemicarbazones as inhibitors of melanogenesis. Bioorg. Med. Chem. Lett. 20: 6794-6796.

Lin H., Su H., Li J., Lin H., 2010. An efficient novel acetate anion receptor based on isatin, J. Braz. Chem. Soc. 21: 541-545.

Lin W.Q., Xie J.X., Wu X.M., Yang L., Wang H.D., 2014. Inhibition of xanthine oxidase activity by Gnaphalium affine extract, Chin. Med J. Peking 29: 225-230.

Lineweaver, H., Burk, D., 1934. The determination of enzyme dissociation constants. Journal of the American chemical society, 56(3): 658-666. 
Malkina A.G., Nosyreva V.V., Albanov A.I., Afonin A.V., Vashchenko A.V., Amosova S.V., Trofimov B.A., 2017. Regioselective N(2)-Hfunctionalization of thiosemicarbazones of aromatic and heteroaromatic aldehydes with acrylonitrile, Synthetic Communications, 47:2, 159-168.

Netalkar P.P., Netalkar S.P., Revankar V.K., 2015. Transition metal complexes of thiosemicarbazone: Synthesis, structures and invitro antimicrobial studies, Polyhedron 100: 215-222.

Pelosi G., Bisceglie F., Bignami F., Ronzi P., Schiavone P., Re M.C., Casoli C., Pilotti E., 2010. Antiretroviral activity of thiosemicarbazone metal complexes, J. Med. Chem. 53: 8765-8769.

Pelosi G., Bisceglie F., Bignami F., Ronzi P., Schiavone P., Re M.C., Casoli C., Pilotti E., 2010. Antiretroviral Activity of Thiosemicarbazone Metal Complexes, J. Med. Chem. 53: 8765-8769.

Şahin M., Koca A., Özdemir N., Dinçer M., Büyükgüngör O., Bal-Demirci T., Ülküseven B., 2010. Synthesis, X-ray crystal structures, thermal and electrochemical properties of thiosemicarbazidatodioxouranium (VI) complexes. Dalton Trans. 39: 10228-10237.

Sarıüney A.B., Saf A.Ö., Coskun A., 2014. A newly synthesized thiazole derivative as a fluoride ion chemosensor: naked-eye, spectroscopic, electrochemical and NMR studies, Spectrochim. Acta A, 128: 575-582.

Smolentsev A.I., Lavrenova L.G., Elokhina V.N., Nakhmanovich A.S., Larina L.I., 2009. Crystal structures of pyridine-4-aldehyde thiosemicarbazone perchlorate and trifluoromethane sulfonate. J. Stuct. Chem. 50: 500-504.

Temel, Y., Ayna, A., Hamdi Shafeeq, I., Ciftci, M. 2018. In vitro effects of some antibiotics on glucose-6phosphate dehydrogenase from rat (Rattus norvegicus) erythrocyte. Drug and chemical toxicology, 41: 1-5.

Temel, Y., Bengü, A. Ş., Akkoyun, H. T., Akkoyun, M., Ciftci, M. 2017. Effect of astaxanthin and aluminum chloride on erythrocyte G6PD and 6PGD enzyme activities in vivo and on erythrocyte G6PD in vitro in rats. Journal of biochemical and molecular toxicology, 31(10): e21954.
Temel, Y., Kocyigit, U. M. 2017. Purification of glucose-6-phosphate dehydrogenase from rat (Rattus norvegicus) erythrocytes and inhibition effects of some metal ions on enzyme activity. Journal of biochemical and molecular toxicology, 31(9): e21927.

Temel, Y., Taysi, M. Ş. 2018. The Effect of Mercury Chloride and Boric Acid on Rat Erythrocyte Enzymes. Biological trace element research, 186: 1-6.

Thanigaimalai P., Hoang T.A.L., Lee K.C., Bang S.C., Sharma V.K., Yun C.Y., Roh E., Hwang B.Y., Kim Y., Jung S.H., 2010. Structural requirement(s) of $\mathrm{N}$-phenylthioureas and benzaldehyde thiosemicarbazones as inhibitors of melanogenesis in melanoma B16 cells, Bioorg. Med. Chem. Lett. 20: 2991-2993.

Thomas, D., Cherest, H., Surdin-Kerjan, Y., 1991. Identification of the structural gene for glucose-6phosphate dehydrogenase in yeast. Inactivation leads to nutritional requierment for organic sulfur", EMBO J. 10: 547-553.

Wang X.M., Yan H., Feng X.L., Chen Y., 2010. 1Pyrenecarboxaldehyde thiosemicarbazone: A novel fluorescent molecular sensor towards mercury (II) ion, Chinese Chemical Letters 21: 1124-1128.

Yusuf M., Jain P., 2014. Synthesis and biological significances of 1,3,4-thiadiazolines and related heterocyclic compounds, Arab. J. Chem. 7: 525552.

Zhang, C., Zhang, Z., Zhu, Y., Qin, S., 2014. Glucose-6phosphate dehydrogenase: a biomarker and potential therapeutic target for cancer. AntiCancer Agents in Medicinal Chemistry (Formerly Current Medicinal Chemistry-Anti-Cancer Agents), 14(2): 280-289.

Zhao H.C., Shi Y.P., Liu Y.M., Li C.W., Xuan L.N., Wang P., Zhang K., Chen B.Q., 2013. Synthesis and antitumor-evaluation of 1,3-selenazolecontaining 1,3,4-thiadiazole derivatives, Bioorg. Med. Chem. Lett. 23: 6577-6579. 